\title{
Lapita pottery from the small islands of north-east Malakula, Vanuatu: A brief overview and implications
}

\author{
Stuart Bedford
}

\begin{abstract}
A series of well-preserved Lapita sites was first identified on the small islands of Uripiv, Wala, Atchin and Vao, Malakula, in northern Vanuatu in 2001-2002. Further excavation on Vao and particularly Uripiv continued until 2011. The pottery shows the standard similarities with Lapita pottery generally but also demonstrates the development of very distinctive regional and even island-specific variation in form and motif design during the Lapita period. It suggests very rapid change in pottery form and decoration soon after initial colonisation of the archipelago; an aspect largely masked by the radiocarbon chronology. It also confirms that regional diversification was well underway during the Lapita period itself. This may relate both to the potential that these communities came from different origin points further west and that even during a single generation a range of factors may have encouraged localisation in a range of practices including pottery production.
\end{abstract}

\section{Introduction}

Archaeological research into Lapita in general and pottery in particular has come a very long way since the 1970s when the distinctive dentate-stamped sherds were generally accepted as belonging to a tradition that continued for 1000 years or more in some regions and was broadly divided into two distinct Western and Eastern styles (Green 1979:43-44). The definition of the varied styles comprising different vessel forms and associated decoration was primarily categorised using chronological, decorative and geographical criteria, with three styles ultimately being identified in the 1980s, Far Western, Western and Eastern (Anson 1986; Green 1979). However, with increasing numbers of sites being excavated and increasing numbers of reconstructable vessels being identified from different regions, it became more difficult to assign new forms and designs into the three-style scheme. A modification was the concept of Lapita Provinces, essentially subgroups designed to break down somewhat the broad hegemonic geographic styles. A Southern Province comprising New Caledonia was initially proposed (Kirch 1997:72-73) and ultimately another three Provinces, Far Western-Western, Western-Central and Eastern, were added to encompass the Lapita distribution (Sand 2001:68). However, the concept of Provinces has never really gained much traction as what specifically constituted a Province apart from 
geographical designations was never particularly clear. The more generally accepted framework is that of Summerhayes $(2000,2001)$, where Lapita is defined primarily in decorative, vessel form and chronological terms, Early, Middle and Late.

While this latter scheme is proving to be the most practical, it is also becoming increasingly obvious that these terms have limited wider distributional application and that it is often difficult to specifically define these styles. In terms of Lapita overall, it is Early Lapita, largely restricted to the Bismarcks, that remains the most clearly identifiable, consisting of the widest range of vessel forms with the most concentrated and fine dentate-stamped motifs (Sand 2015; Summerhayes 2000). Rare examples of key definitive aspects of Early Lapita can also be found as far east as Vanuatu and New Caledonia (Bedford 2015:37, Figure 3) but not beyond. Middle Lapita can be contrasted with Early Lapita and there are a series of motifs that can be identified as widespread across the Lapita distribution. There is a reduction in the number of vessel forms and less concentrated design motifs, but there are also indications that increasing regional variation is beginning to develop. Across the distribution, Late Lapita displays significant regional variation with a loss of the rigidly structured design motifs and standard vessel forms (Bedford 2015; Burley 2007; David et al. 2011; Sand et al. 2011) and therefore requires archipelago- and even islandspecific definition. There does remain, however, indications of some level of interconnectedness across the distribution in the form of the widespread appearance of distinctive decorative techniques, such as shell impression, and motifs, such as the simple zigzag created through a rocking motion of a straight stamp.

More recently and following the reconstruction of Lapita vessel forms and design motifs from a selection of sites located in both Near and Remote Oceania, Sand has argued that there was a 'clear need to focus some of our studies on the details of Lapita variation, in order to highlight the diversity of the early Oceanic tradition' (2015:162-165). Sand laments the lack of attention to the reconstruction of vessel forms from most Lapita sites (2015:162), but this has always been hampered by both the fragmentary condition of the vast number of recovered sherds and the often very limited areas of sites that are excavated, greatly reducing the possibility that a series of key sherds from single vessels, essential for full reconstruction, will be recovered.

The poor preservation of Lapita sites and the generally small nature of the sherds are what led to the initial focus on motif comparisons (Anson 1986; Green 1979:43), which has continued to be a major area of research (Chiu and Sand 2005; Noury 2005, this volume). However, as highlighted by Burley and LeBlanc, there are dangers in continuing to place too much emphasis on quantitative comparison of motif suites as attributes, as the complexity of dentate-stamped application or position on a vessel can be equally suggestive of different periods and regional connections or divergence (2015:181; see also Chiu this volume).

This paper addresses Sand's call for detail on Lapita variation by focusing on pottery recovered from the small islands of north-east Malakula, northern Vanuatu (Figure 11.1). It presents a range of primarily dentate-decorated sherds and a more limited number of associated vessel forms that demonstrate both regional variation and lingering connections. It suggests that rapid regional change in pottery form and decoration, which is masked by both broad categorisations of Lapita pottery and radiocarbon dates, could be occurring across much of the Lapita distribution. 


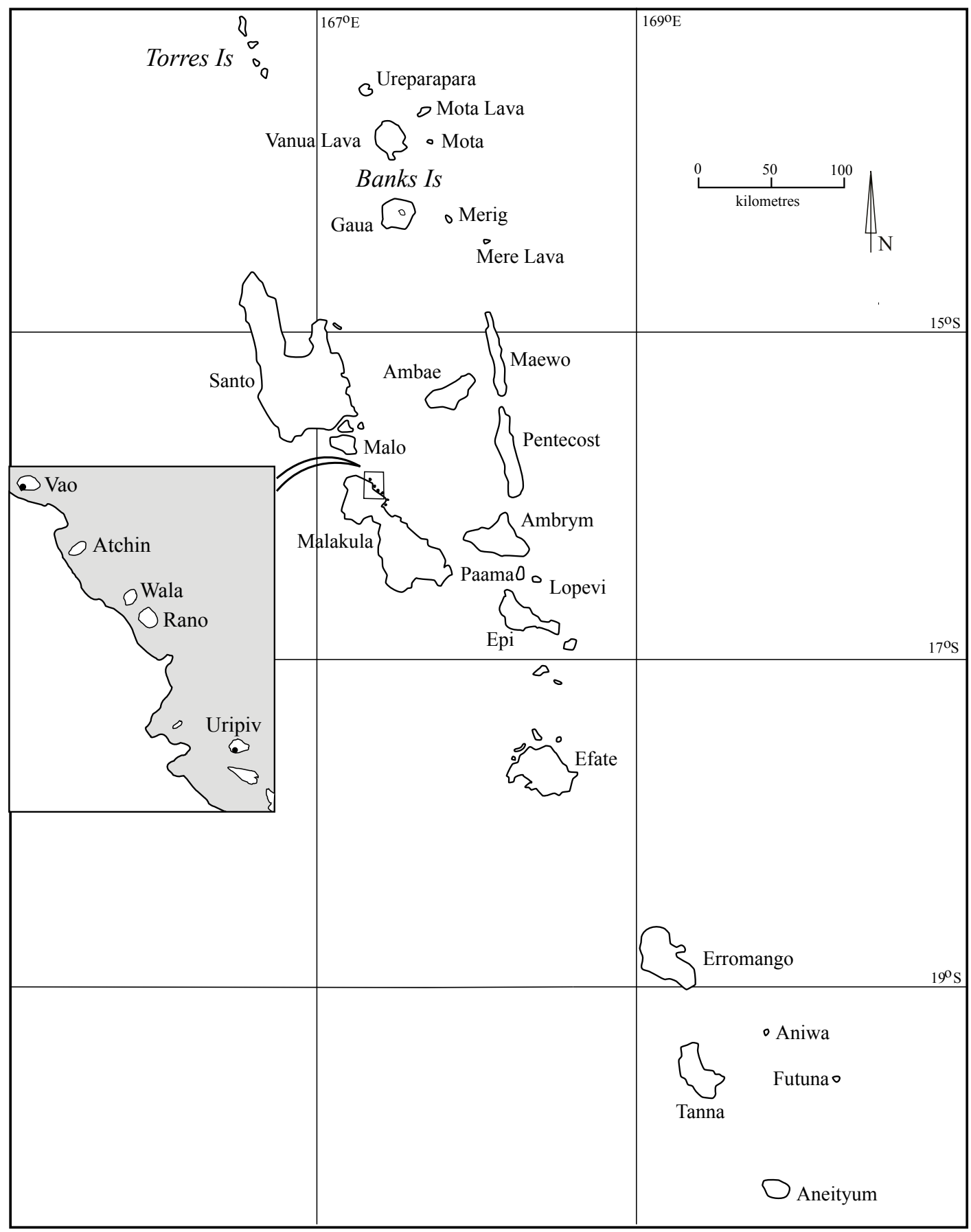

Figure 11.1. Vanuatu and north-east Malakula.

Source: Stuart Bedford. 


\section{Sites and chronology}

Excavations on the islands of north-east Malakula commenced in 2001 as part of a research and training program in collaboration with the Vanuatu Cultural Centre, its staff and their network of 'fieldworkers'. ${ }^{1}$ The islands are small, all less than $2 \mathrm{~km}^{2}$, low-lying and surrounded by fringing reefs, apart from sheltered sandy beaches on the south-western coasts. The islands are also subject to regular uplift (Taylor et al. 1980) and ashfall from the nearby volcanically active island of Ambrym (Robin et al. 1993). All of these aspects helped narrow down potential areas for finding colonising sites and guided the survey methodology that was applied. There was no sign of any Lapita pottery or other associated artefacts on the surface, and so it was determined that test pitting across the uplifted back beaches was required if sites were to be found. Ultimately Lapita settlements were found on Uripiv (2001), Wala, Atchin and Vao (2002) (Bedford 2003:152155). All were located above and parallel to the foreshore in sheltered beach zones facing the large island of Malakula. The sites on Uripiv and Vao proved to the best preserved and additional, more extensive excavations were carried out on Vao in 2003-2004 and on Uripiv in 2009-2011 (Bedford 2006a, 2007; Bedford et al. 2011).

The sites were all generally very well-sealed and preserved through a combination of tectonic uplift, accumulated debris from later habitation in the same area and overlying tephra-laden and cyclonic sand deposits (Bedford 2007). The primary objective of the fieldwork once the Lapita sites had been found on these islands was to establish the extent of the sites and identify any spatial and temporal variation during Lapita and later-period occupation. Excavations in various locations across Uripiv, in conjunction with the regular inspection of newly dug construction features over many years, have also provided stratigraphic and chronological detail for the wider island landscape. The general stratigraphy at all four Lapita sites is remarkably similar (Figure 11.2), as is the Post-Lapita expansion and later settlement across the islands. The Lapita settlements are established directly on the beach terraces and ultimately expand to cover 3000$4000 \mathrm{~m}^{2}$ in area as defined by midden deposits with a dentate-stamped component. Villages remain in these coastally orientated positions for around 1000 years, slowly expanding over time. A distinctive change in the stratigraphy of the sites begins at c. $2300 \mathrm{cal}$. BP, when coral gravel sourced from the foreshore begins to be brought into the sites to act as a free-draining surface for household compounds. These surfaces were continually renewed and in many areas of the sites this layer is up to $50 \mathrm{~cm}$ thick. Over a c. 500-year period these Post-Lapita settlements continue to expand in the same coastal zone to over $10000 \mathrm{~m}^{2}$ in area, as defined through the imported coral gravel layer.

There is substantial disruption at c. $1800 \mathrm{cal}$. BP with the massive Ambrym caldera-forming eruption that showers the whole region with ash (MaCall et al. 1970; Robin et al. 1993). Whether such an event required evacuation or not on the islands of Malakula has yet to be determined, but the eruption proved to be a temporary hiatus and people were immediately presented with a radically transformed landscape. The addition of the ash greatly enriched the wider landscape and facilitated settlement across entire islands from this period. The ash from the initial eruption has been augmented ever since by subsequent eruptions, and today there is a clearly identifiable ash-rich layer at least $50 \mathrm{~cm}$ thick in most areas of the islands. The only excavations undertaken in the interior of these islands was on Uripiv at a settlement site known as Pirpir, now defined by linear mound features comprising midden material, which has returned dates of $1500 \mathrm{cal}$. BP. The settlement pattern on the small islands at contact, which included stone ceremonial sites or nasara surrounded by villages spread across the island (Layard 1942), dates to the last 500 years.

1 Volunteers spread throughout the country who act as Vanuatu Cultural Centre representatives and who promote indigenous custom and culture. 

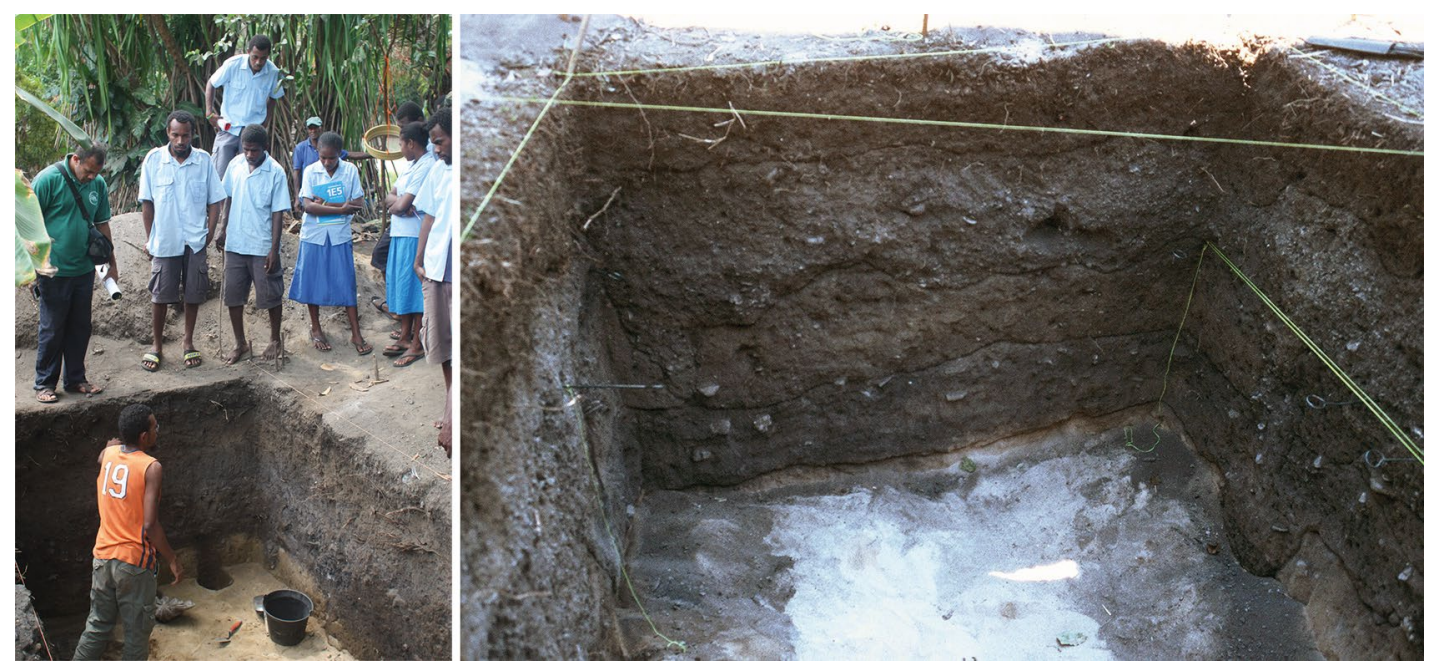

Figure 11.2. Section of an area excavation on Uripiv (upper) and Vao Islands showing stratigraphic layering that is broadly found across all small islands of north-east Malakula. The Vao section is $2 \mathrm{~m}$ wide. Source: Stuart Bedford.

The total area excavated at the Lapita site on Uripiv was $106 \mathrm{~m}^{2}$, initially comprising a series of 1 by $1 \mathrm{~m}$ test pits to define the limit of the site and any internal chronological variation. Larger area excavations were subsequently undertaken focusing on the earlier core of the site and a cemetery area located to the north of the Lapita midden zone. Similarly, on Vao an initial grid of 1 by $1 \mathrm{~m}$ test pits (24) determined the site extent and then two further 3 by $2 \mathrm{~m}$ areas (A and B) were excavated in places where both the deepest and earliest deposits were identified. A total of $36 \mathrm{~m}^{2}$ was excavated on Vao (Bedford et al. 2011).

A broad chronology of the Lapita occupation was provided through radiocarbon dates (Table 11.1). Dating was more effective in the earliest phase of occupation where the calibrated standard deviation was limited, but in the later phases of occupation the flat section of the calibration curve returned standard deviations that spanned hundreds of years. This masked variation and rapid change that occurred across and within the sites during Lapita occupation. Using other criteria, such as variation in vessel form and design, the presence of extinct fauna and exotic obsidian, initial occupation zones of the Lapita settlements were able to be identified. There is little reason to doubt that these sites represent initial colonising sites on these islands and in the case of Vao an initial colonising site for the wider area. As noted by Green (2003:114, footnote 18) such sites can be identified through:

early known dates among a series of early Lapita sites in a particular region, oversized shells of great maturity, extinct or extirpated land birds and terrestrial animals, heavy exploitation of marine resources, items like obsidian or pottery with origins in the regions or islands to the west of the site in question.

The excellent preservation of the Lapita sites from these islands cannot be overemphasised. They show very limited disturbance after $2300 \mathrm{cal}$. BP when the coral gravel surface began to be imported, ultimately providing a thick and very durable protective layer across the top of the Lapita deposits. The addition of periodic ashfalls since $1800 \mathrm{cal}$. BP has provided further protection, and today all Lapita deposits are located at a minimum depth of 50-60 cm below the surface. The ideal conditions of preservation were highlighted at these sites by the evidence that a large number of the Lapita dentate-stamped sherds revealed painting. Initial signs of painting began to be uncovered in 2001 and 2002 during excavations on Uripiv, Atchin and Vao. Further excavations on Vao in 2003 and 2004 returned a greater number of large painted 
sherds. Lime infill, argued to be a remnant of the painting, was also frequently recorded (Bedford 2006b). One of the advantages of the limited mixing or post-depositional disturbance is the high number of conjoining sherds that can be retrieved even from a 1 by $1 \mathrm{~m}$ test pit. This has provided greater potential for full reconstruction of designs and vessel forms.

Chronological and ceramic variations were found on Vao and Uripiv across the Lapita sites. An earlier core to the sites was able to be identified, which was where the pottery displayed a greater range of vessel forms and decoration that was generally applied in more detail using finer dentate stamps. As the settlements expanded, dentate stamping became very simple and associated vessel forms were reduced to only one or two types. Radiocarbon dates for the earlier phase of settlement on Vao and Uripiv are almost identical. On Vao these are (all at 68.2 per cent probability) 2996-2880 cal. BP and 2925-2800 cal. BP and on Uripiv 2941-2865 cal. BP and 2929-2845 cal. BP (see Table 11.1). Dating the end of the dentate-stamped phase is severely hampered by the dates falling in a flat section of the calibration curve.

Table 11.1. Radiocarbon dates from Lapita layers on Uripiv and Vao Islands.

\begin{tabular}{|c|c|c|c|c|c|c|c|}
\hline $\begin{array}{l}\text { Sample } \\
\text { number }\end{array}$ & Island & Unit & $\begin{array}{l}\text { Layer/depth } \mathrm{cm} \\
\text { below datum }\end{array}$ & Material & $\begin{array}{l}\delta 13 C \\
\pm 0.2\end{array}$ & $\begin{array}{l}\text { Uncalibrated } \\
\text { date BP }\end{array}$ & $\begin{array}{l}\text { Calibrated date BP } \\
\text { (68.2\% and } 95.4 \% \text { prob.) }\end{array}$ \\
\hline Wk-10413 & Uripiv & TP1 & $90-100 \mathrm{~cm}$ bd & unidentified charcoal & -24.7 & $2423 \pm 94$ & $2698-2352 ; 2745-2365$ \\
\hline Wk-13150" & Uripiv & TP5 & $100-110 \mathrm{~cm} \mathrm{bd}$ & unidentified charcoal & -25.6 & $2504 \pm 47$ & $2724-2493 ; 2745-2380$ \\
\hline Wk-10414 & Uripiv & TP9 & $150-170 \mathrm{~cm} \mathrm{bd}$ & unidentified charcoal & -24.5 & $2681 \pm 74$ & 2860-2745; 2991-2541 \\
\hline Wk-13151" & Uripiv & Area B & $100-110 \mathrm{~cm} \mathrm{bd}$ & unidentified charcoal & -25.6 & $2481 \pm 42$ & $2710-2490 ; 2725-2379$ \\
\hline Wk-20009 & Uripiv & TP14 & $135 \mathrm{~cm}$ bd & marine shell Trochus sp. & 3.3 & $2858 \pm 39$ & $2707-2572 ; 2726-2486$ \\
\hline Wk-20010 & Uripiv & TP14 & $140 \mathrm{~cm}$ bd & $\begin{array}{l}\text { marine shell Lambis } \\
\text { lambis }\end{array}$ & 0.7 & $3181 \pm 40$ & $3046-2913 ; 3110-2850$ \\
\hline $\begin{array}{l}\text { SANU- } \\
32013^{*}\end{array}$ & Uripiv & Area F.4 & $110-120 \mathrm{~cm}$ bd & nut charcoal & -28 & $2550 \pm 35$ & $2748-2540 ; 2753-2495$ \\
\hline $\begin{array}{l}\text { SANU- } \\
32014^{*}\end{array}$ & Uripiv & Агеа F.4 & $120-130 \mathrm{~cm}$ bd & nut charcoal & -28 & $2780 \pm 30$ & $2929-2845 ; 2953-2793$ \\
\hline $\begin{array}{l}\text { SANU- } \\
32015\end{array}$ & Uripiv & Area F.4 & $130-140 \mathrm{~cm}$ bd & nut charcoal & -27 & $2800 \pm 25$ & $2941-2865 ; 2965-2807$ \\
\hline $\begin{array}{l}\text { SANU- } \\
32016^{*}\end{array}$ & Uripiv & Area F.1 & $120-130 \mathrm{~cm}$ bd & nut charcoal & -28 & $2550 \pm 30$ & $2748-2542 ; 2750-2500$ \\
\hline Wk-13147 & Vao & TP 3 & $150-160 \mathrm{~cm}$ bd & unidentified charcoal & -24 & $2464 \pm 48$ & $2704-2443 ; 2714-2365$ \\
\hline Wk-14041" & Vao & TP11 & $190-200 \mathrm{~cm}$ bd & unidentified charcoal & -27.5 & $2839 \pm 40$ & 2996-2880; 3070-2851 \\
\hline Wk-14040 & Vao & Area A.1 & 130-140 cm bd & unidentified charcoal & -23.7 & $2776 \pm 38$ & $2925-2800 ; 2960-2780$ \\
\hline
\end{tabular}

Samples included shell and charcoal using both AMs" and standard radiometric methods. The radiocarbon determinations were calibrated by Fiona Petchey, University of Waikato, Radiocarbon Dating Laboratory, using OxCal v. 4.2.4 (Bronk Ramsey 2013) and the IntCal13 atmospheric curve or the Marine 13 calibration curve (Reimer et al. 2013). Marine samples were calibrated with a $\Delta R$ value of $29 \pm 28{ }^{14}$ C yrs (Petchey et al. 2008).

Source: Author's summary table.

The chronological variation found across the sites, which was indicated by the pottery and radiocarbon dates, was further confirmed by recovered obsidian and extinct faunal remains. Surprisingly small amounts of obsidian were found on the islands, a total of only four pieces, three from Vao and one from Uripiv. Banks Islands (Vanua Lava, three pieces) and Talasea (one piece) obsidian were found, the single piece of the latter recovered from the earlier core area of the Vao site. The radiocarbon dates suggest some overlap of the Malakula sites with Makue on Aore Island to the north and Teouma of Efate to the south, but much greater quantities of obsidian have been recovered from those sites (Makue 120 and Teouma 124) (Constantine 
et al. 2015; Galipaud et al. 2014). While it is difficult to distinguish the two Malakula sites on their radiocarbon chronology, one feature that stands out as spectacularly different is the number of extinct tortoise bones. Both sites returned rich faunal deposits (see Ono et al. this volume) but 1672 tortoise bones were recovered on Vao, while on Uripiv only a single bone was identified (Hawkins et al. 2016). This indicates that Vao was almost certainly occupied earlier than Uripiv and may even have acted as an initial and primary colonising Lapita centre in northeastern Malakula. The pottery and obsidian suggest a later settlement for the Malakula sites than at Makue and Teouma. The radiocarbon chronology, however, is not fine-grained enough to differentiate significant changes that may be occurring over a very short period.

\section{Pottery}

Initial descriptions of the Lapita dentate-stamped pottery from the small islands characterised much of it as crude in application with simplified and enlarged motifs and in one case only halffinished (Bedford 2003:154). There were also a limited number of decorated vessel forms. While this description remains applicable to most of the collection, the subsequent excavation of earlier components of the sites on Vao and Uripiv, along with larger sampled areas overall, show that some modification is required, and more definitive conclusions regarding the composition of the Lapita pottery suite from both islands can now be presented.

The range of decorated vessel forms remains limited (Figures 11.3-11.5). They include carinated vessels, shallow and deeper incurving bowls, and globular outcurving rim vessels. Plain, globular outcurving rim vessels are also found in association as is typical of all Lapita sites. Flat dishes are present but are very rare, only one example on each island. The sites are dominated by carinated vessels with incurving rather than outcurving rims, a form that is generally much rarer across the Lapita distribution (see Bedford 2015: Figure 4d; Sand 2010: Figure 115a; Sand 2015: Figure 21; Summerhayes 2001), although this apparent rarity may be due to the difficulty of determining vessel form from small sherds (Sand 2015: Figure 33). The carinations on the vessels from Vao and Uripiv also often tend to be softly curved rather than angular (Figures 11.3b and 11.4i) and over time disappear altogether. A number of the incurving vessels from Uripiv also have a very distinct stepped rim (Figures 11.3b, 11.4g, 11.4h, 11.5a and 11.5b) and in one case a step below the carination (Figure 11.5a). Cylinder stands are absent, as are stands for flat dishes, and there are no open bowls. Dentate stamping is applied with the usual range of short and longer, straight and curved tools and impressed circles but there is no evidence of excising. Applied relief in the form of nubbins both on the carination and above it was found only on Vao (Figures 11.4d, $11.4 \mathrm{~g}$ and $11.4 \mathrm{j})$. Motif designs are many and varied and while some are simple, they cover much of the upper part of the vessel (Figures 11.3a, 11.3b and 11.4f). Devolved face motifs might also be suggested in a number of cases (Figure 11.3a and 11.3b). Evidence of painting in the form of lime infill and/or a lime wash across the dentate motifs, often with the addition of a haematite red, was frequent at both sites (Bedford 2006b). Incised decoration is present from the earliest layers of the sites and is the last decorative technique still applied at the end of Lapita. This is consistent with incised decoration across much of the entire Lapita distribution, where it shows remarkable conservatism in terms of design and application to vessel form over time and space (Figure 11.5e). Plain globular vessels with outcurving rims continued throughout the sequence and ultimately dominated the post-dentate-stamped phase at least until c. $2000 \mathrm{cal}$. BP. 
a
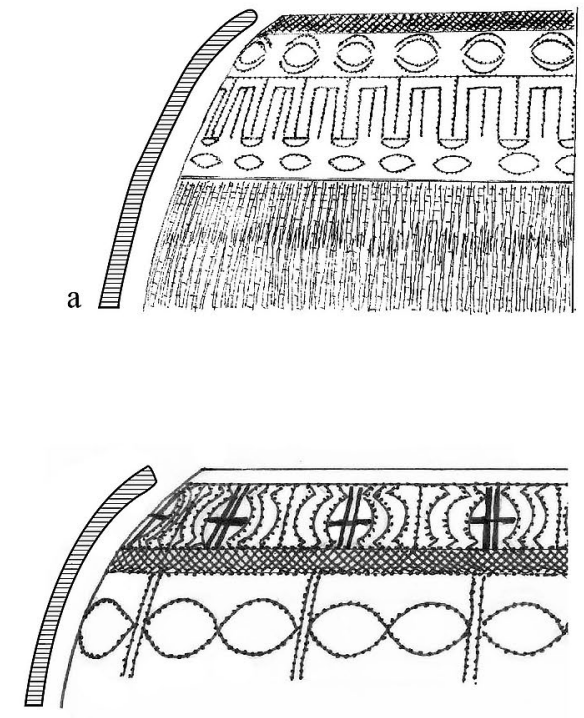

b

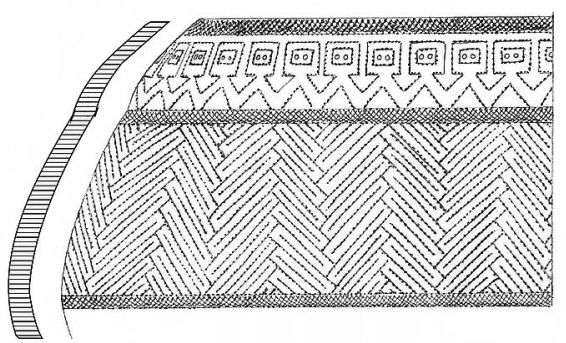

d
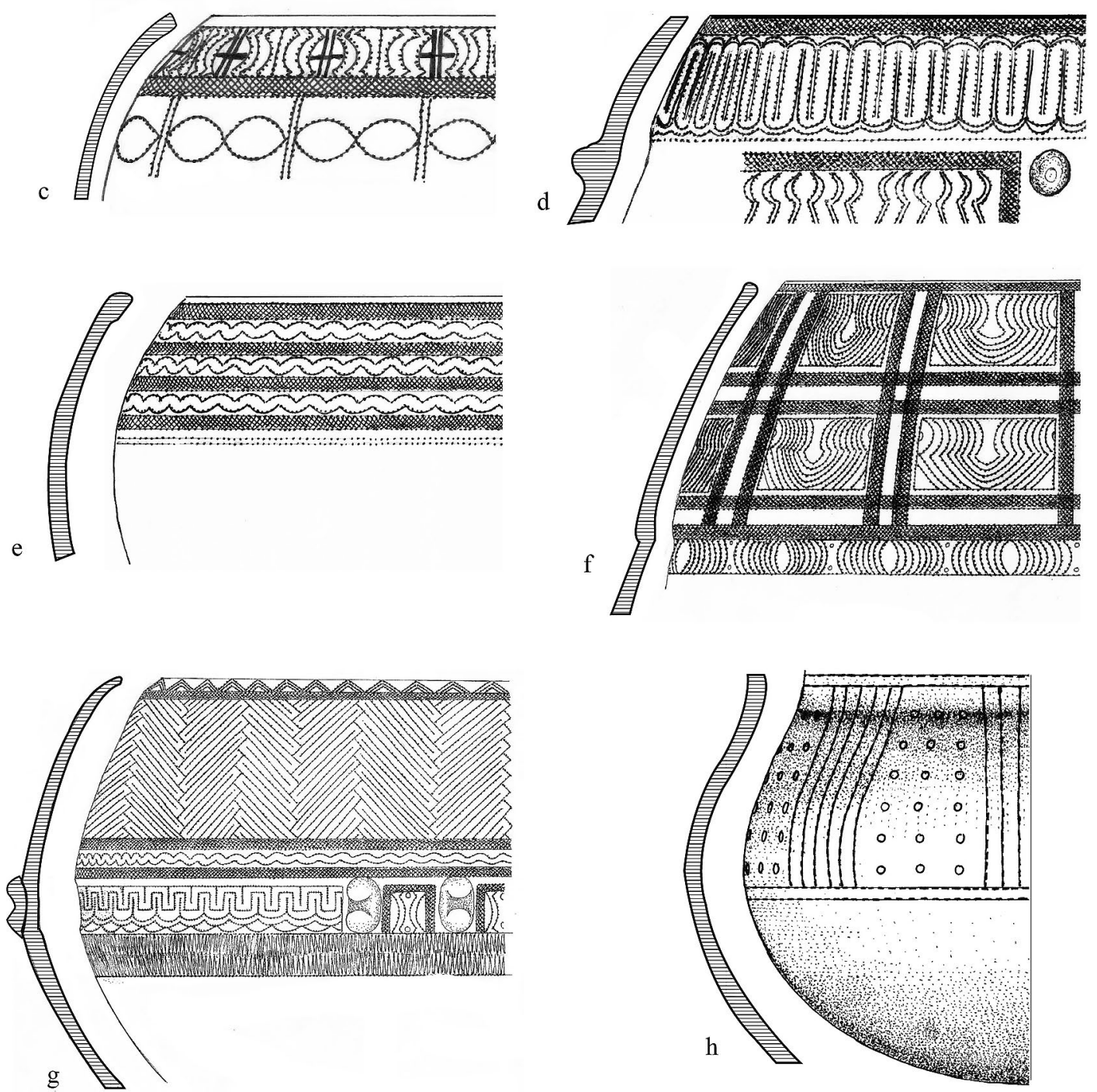

Figure 11.3. Reconstructed vessel forms and associated dentate-stamped decoration from Vao Island. (A) globular vessel with incurving rim and devolved face motif; (B) carinated vessel with step at rim, with possible devolved face motif; (C) globular vessel with incurving rim; (D) incurving rim vessel with step on rim and applied relief; (E) globular incurving rim vessel; (F) incurving rim vessel with concentrated dentate-stamping that also showed clear signs of paint; (G) incurving rim vessel with nubbins at soft carination; ( $\mathrm{H}$ ) globular outcurving rim vessel with expanded design of dentatestamped parallel lines enclosing impressed circles.

Source: Illustrations drawn by Siri Seoule. 


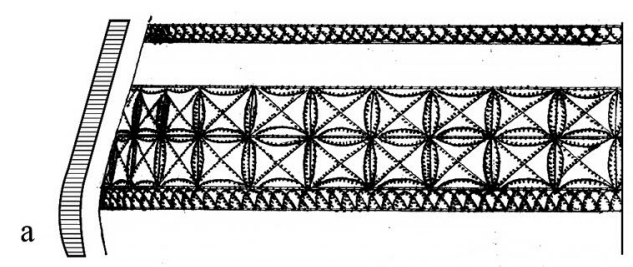

b
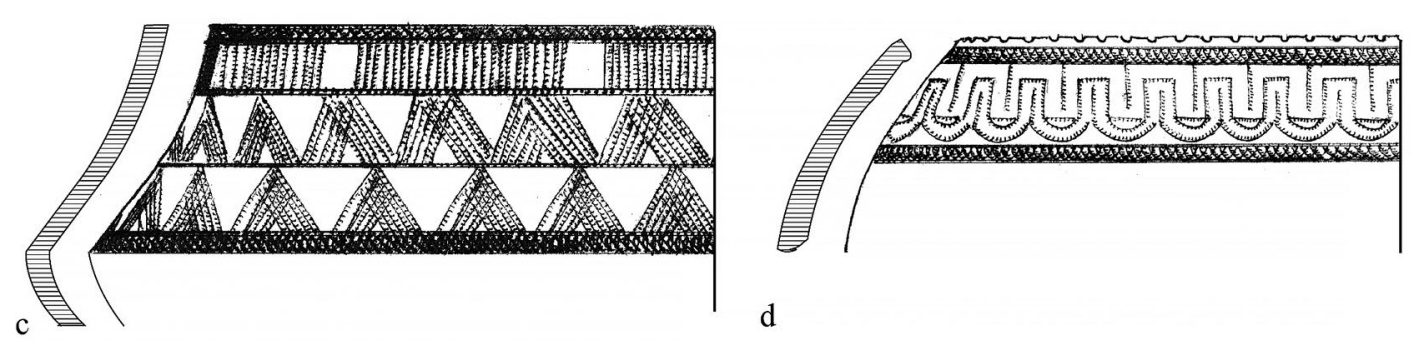
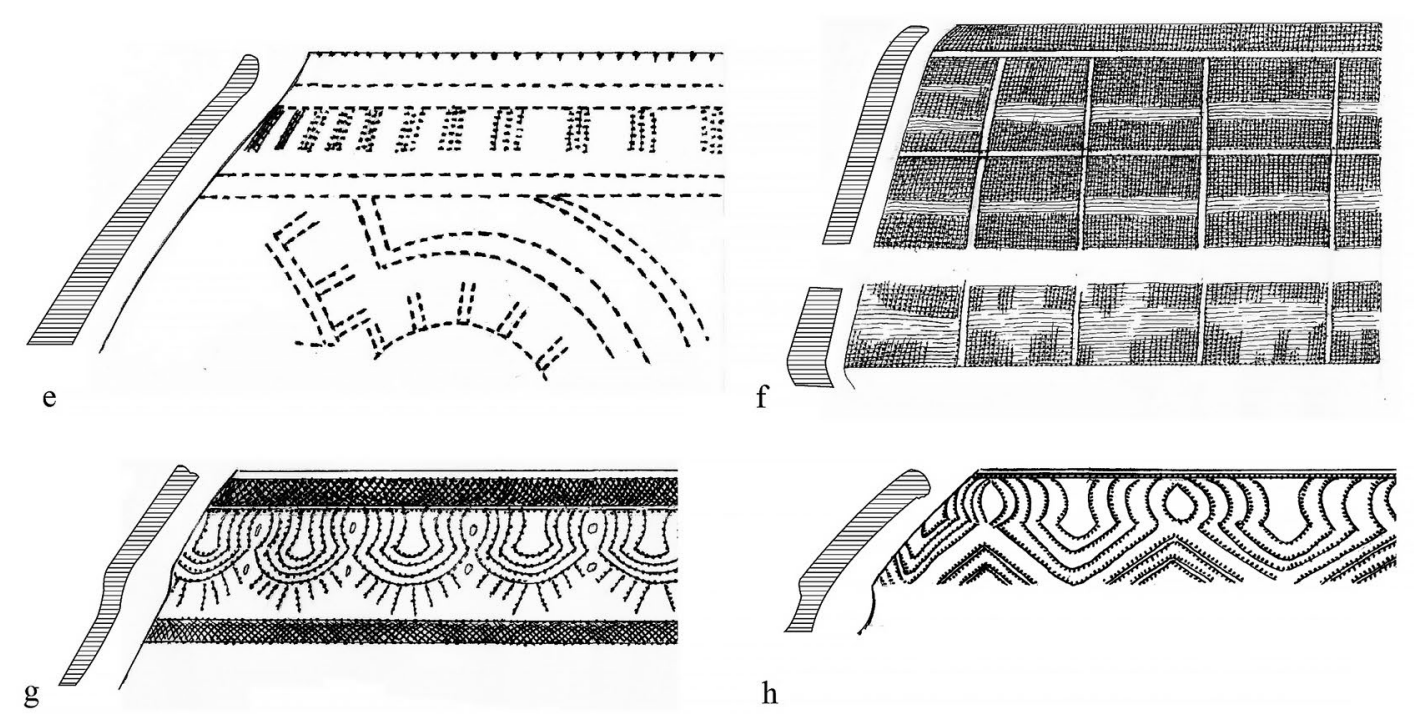

$\mathrm{h}$
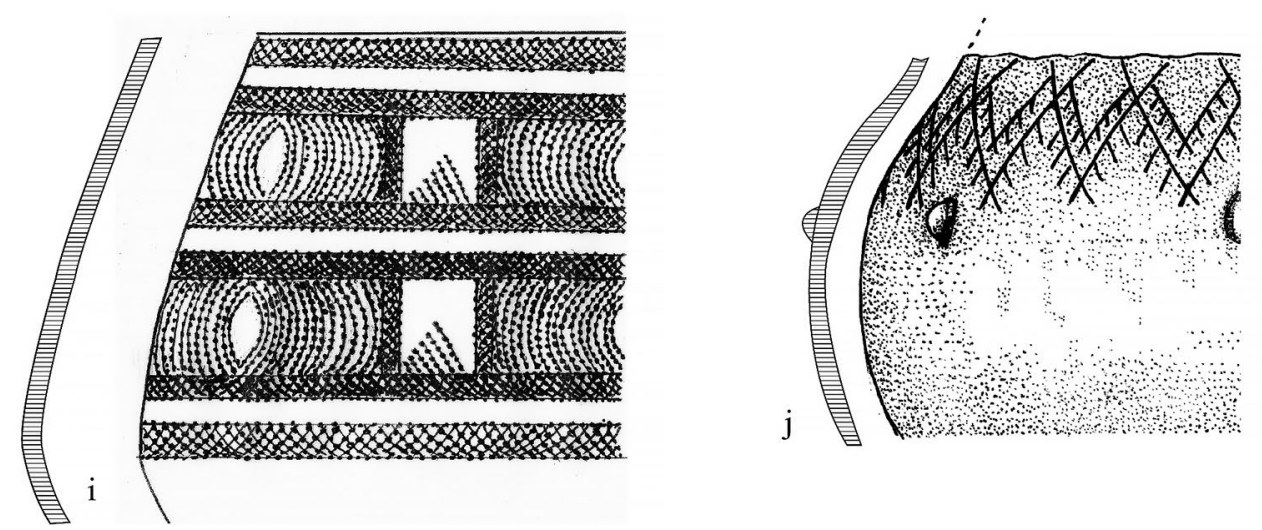

Figure 11.4. Reconstructed vessel forms and associated dentate-stamped decoration from Vao Island. (A) vessel with less-pronounced carination, rim-lip form not known; (B) vessel with sharp carination, rim-lip form not known; (C) carinated vessel with incurving rim; (D) globular vessel with incurving rim; (E) incurving rim vessel with exploded dentatestamped motif; (F) carinated vessel with incurving rim and very heavily dentate-stamped; (G) incurving rim vessel with step at upper rim; (H) incurving rim vessel with step at upper rim; (I) carinated vessel with incurving rim (previously illustrated as fully painted vessel (Bedford 2006b)); (J) globular outcurving rim vessel with simple dentate-stamping and nubbins.

Source: Illustrations drawn by Siri Seoule. 

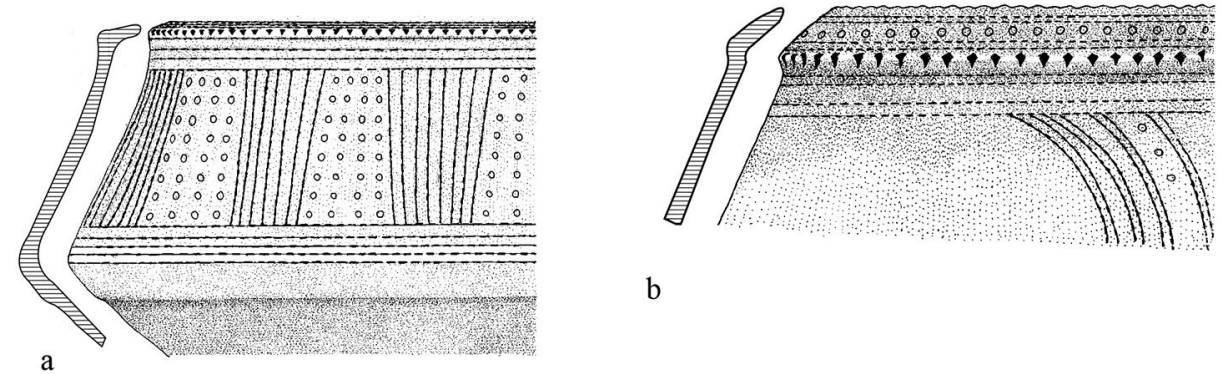

b

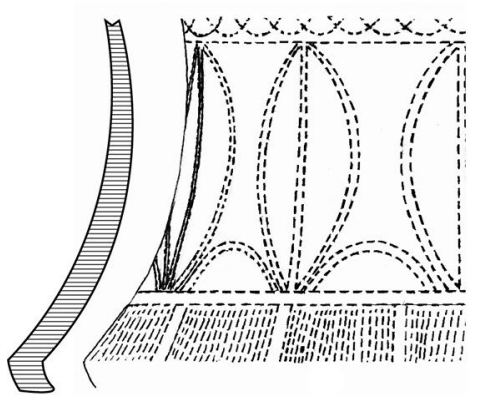

$\mathrm{c}$
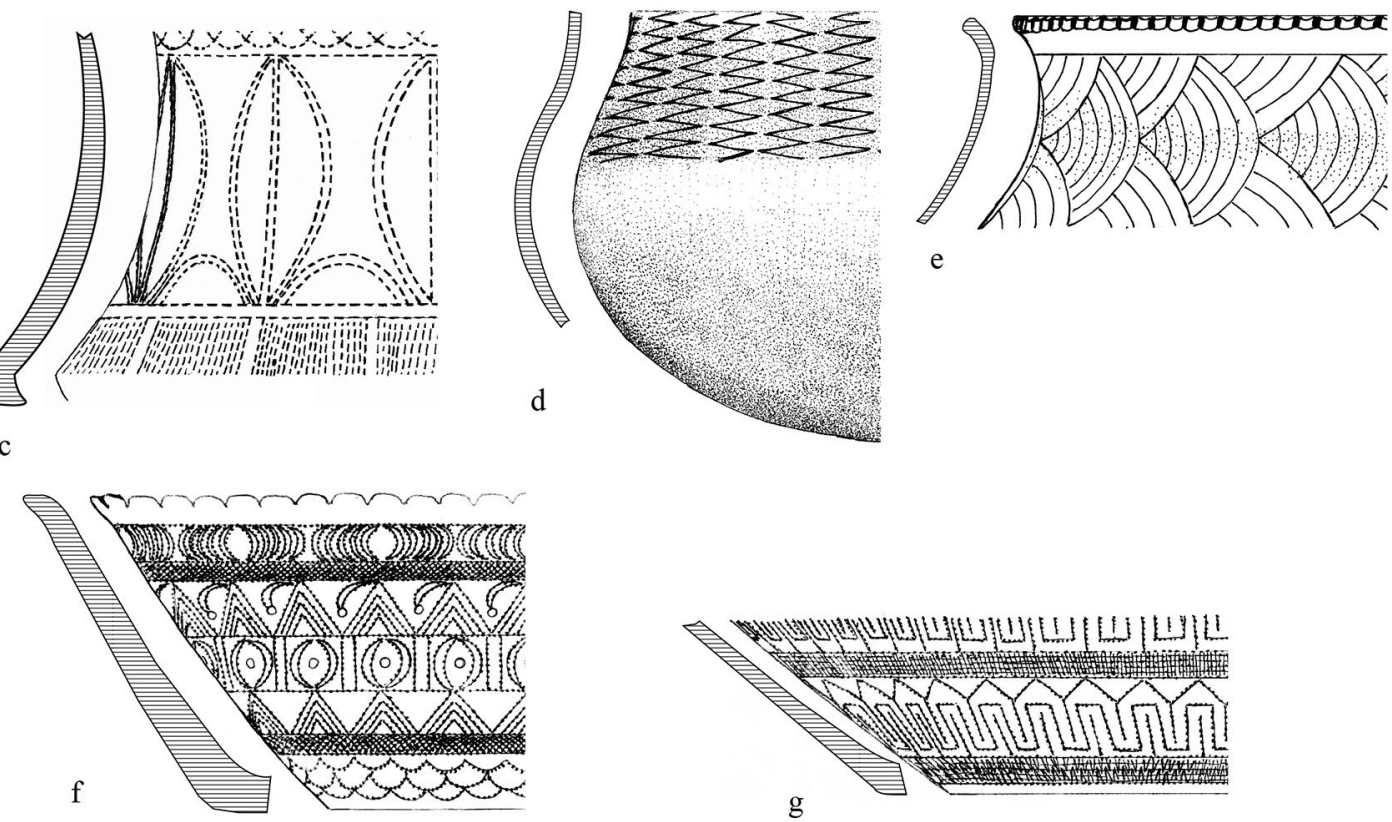

Figure 11.5. Reconstructed vessel forms and associated decoration, both dentate-stamped and incised from Uripiv (a-c, g) and Vao (d-f) Islands.

$(A-B)$ incurving carinated vessels with extra carination at rim; $(C)$ carinated vessel with outcurving rim and exploded dentate motif; (D) globular outcurving rim vessel with dentate-stamped zigzag motif; (E) globular outcurving rim vessel with incised motif; ( $\mathrm{F}-\mathrm{G}$ ) flat dishes from Vao and Uripiv.

Source: Illustrations drawn by Siri Seoule.

Another distinctive feature is the generally small size of the decorated vessels. The four fully reconstructed carinated vessels from Teouma all had diameters of more than $300 \mathrm{~mm}$ and two of them more than $400 \mathrm{~mm}$ (Bedford et al. 2007). Although it is difficult to be definitive, as many of the rim sherds are not large enough for the accurate measurement of the diameter, the vessels from Vao and Uripiv are mostly no more than $200 \mathrm{~mm}$ in diameter. The high labour input in elaborate vessel construction, implicit in the much larger vessels found at Teouma and many other contemporary and earlier sites further west, appears to be notably reduced at these sites, perhaps signalling some level of social fragmentation or divergence (Clark 2007:297).

\section{Local and regional comparisons}

There are a limited number of sites elsewhere in Vanuatu where robust comparisons can be made with the Malakula pottery. While site numbers recorded in the archipelago are increasing, most have returned limited number of sherds and/or reconstructed vessel forms. Those that are most useful here are the sites just to the north, Makue on Aore Island (Noury 2013; Noury 
and Galipaud 2011) and various sites on Malo Island (Hedrick n.d.; Noury 2013) and the Teouma site on Efate to the south (Bedford et al. 2010). While there are always concerns that comparisons are hampered by vessel fragmentation, it is clear that many of the standard Lapita motifs are present and shared with the above sites, but what is most striking is the variation in their arrangement and combination along with the associated distinctive vessel forms. At a cursory glance, it would seem that very few of the motif combinations and their respective vessel forms are found at other sites. One that appears to have some parallels in terms of design layout is bounded impressed circles, which are seen on two vessel forms on Malakula (Figures 11.3h and 11.5a), while a variation of this design is found in Tonga (David Burley pers. comm.). The globular incurving rim vessel form, which so dominates at both sites, is not recorded on Aore or Malo but there is a maximum of eight examples at Teouma, all of which display different motif combinations (author's unpublished data). Further afield such vessel forms are recorded in New Caledonia where are they noted as being relatively rare and having small diameters (c. $200 \mathrm{~mm}$ ) (Sand 2010:124-125). Globular incurving rim vessels are recorded much further west at Anir, but again appear to be relatively rare (Sand 2015: Figure 21). It is a form that has been recorded as far east as Tonga (Burley et al. 2002: Figure 2), but as yet appears absent during the Lapita period in Fiji (Clark and Anderson 2001: Table 2).

The other dominant vessel form from the Malakula sites is carinated incurving vessels with two distinct forms, those with carination (often subtle) and parallel rim (Figures 11.4c and 11.4i) and forms that include a step or an extra carination towards the end of the rim (Figure 11.5a). The former is noted on Malo (Hedrick n.d., Type C) and is found at Teouma (author's data). It is also found more widely across the distribution in Remote Oceania, in the Reefs-Santa Cruz (Sand 2015: Figure 33), New Caledonia (Sand 2010: Photo 59) and Tonga (Burley et al. 2002: Figure 2). Definitive identification of this form in the Near Oceanic region remains elusive. The vessel form identified only on Uripiv, with a step or carination near the upper part of the rim and another step below the lower carination, appears to be unique to Vanuatu, with a number of examples from Malakula (Figure 11.5a) and a single example known from Teouma (Bedford 2015: Figure 4f).

As noted above, the Lapita-period incised motifs and vessel forms recovered from Vao and Uripiv (see Figure 11.5e) confirm the remarkably conservative nature of these types across the Lapita distribution from Mussau to Tonga and from Early to Late (Burley et al. 2001; Sand 2010:104-105). The expanded zigzag motif, both dentate (Figure 11.5d) and incised, as a final decorative gasp is seen from north to south in Vanuatu (Bedford et al. 2016:124) and again right across the Lapita world (Sand 2010:146). The divergence of pottery styles during the Lapita period in Vanuatu continues into the Post-Lapita period on Malakula, with none of the immediately Post-Lapita styles found in the central and south of the archipelago showing any affiliations with those found in Malakula.

\section{Discussion}

The Lapita pottery recovered from the sites on the small islands of north-east Malakula appears to represent a distinctive regional variant of the tradition that begins to develop soon after initial arrival in the archipelago. While there remains some level of doubt as to how robust these conclusions are due to issues such as sampling and/or poor preservation of sherds from other sites, the comparison with larger collections available from Vanuatu and other regions indicates that Lapita pots from these small islands are distinctive in terms of motif combinations and 
vessel forms. Lapita was never a monolithic cultural entity governed from the 'Homeland'. It was changing rapidly over time and space even within generations and certainly between them, and particularly so when the rapid expansion into Remote Oceania was underway (Best 2002).

Lapita communities were initially producing pottery that was an integral component of their cultural baggage, but finding themselves in new and increasingly dispersed landscapes provided new challenges and opportunities. This was particularly the case in Remote Oceania where these populations were entering unoccupied islands, rich in natural faunal food resources that seemed to stretch on endlessly. In Remote Oceania, people became highly mobile, exploring, colonising and interacting at a whole series of regionally based levels and different directions over several generations with continuing input from populations from the west. Elements of this might be seen in the preliminary ancient genetics generated for some of the Vanuatu Lapita sites. At Teouma the analysis of the aDNA of four individuals indicates largely Asian heritage (Lipson et al. 2018; Skoglund et al. 2016), while at the slightly later site of Uripiv individuals shared a mixed Asian and Papuan heritage (Posth et al. 2018). Morphological study of Vanuatu skeletal remains and other comparative samples reinforces the idea of population change in western Remote Oceania as occurring within the Lapita period (Valentin et al. 2016).

The symbolic meaning of the elaborate dentate-stamped vessels became rapidly diluted with increasing distance and time, and more mixed populations. This rapid change is, however, often masked by both the commonly applied broad categories or labels and the radiocarbon chronologies. Radiocarbon results have tended to take precedence and dominate in discussions of site chronology with often limited assessment of the materials recovered and in the case of pottery the processes and rates of cultural transmission and transformation (e.g. Denham et al. 2012).

The Lapita sites on Malakula highlight the potential for the rapid development of local and regional pottery variation that is characterised by the Late Lapita style across the entire distribution. Late Lapita does not generally demonstrate any sign of synchronous change, apart from the appearance of shell impression and the expanded zigzag motif. Rather, it is exemplified by increasing regional divergence and locally distinctive decoration and vessel forms (Bedford and Galipaud 2010; Burley 2007; Burley and Dickinson 2004; Clark 2010; David et al. 2011; Sand et al. 2011). If this is indeed the scenario during the Lapita period, it is hardly surprising that if pottery in any one region continued to be made into the Post-Lapita period then continuing variability would be expected (Bedford 2006a:157-192). Malakula provides further evidence of such diversification with its Post-Lapita pottery, predominately a plainware, showing no affiliation with sequences of a similar period in the centre and south of the archipelago.

\section{Acknowledgements}

All chiefs, landowners and communities of the Small Islands have been remarkably tolerant, supportive and interested in the research over many years. Numa Fred Longga, the curator of the Malakula Cultural Centre has been an exceptional guide throughout. Funding was provided variously by: the Sasakawa Pacific Island Nations Fund; the Royal Society of New Zealand (Marsden Fast-Start 9011/3602128; 04-U00-007); a National Geographic Scientific Research Grant (7738-04); and the Australian Research Council (DP0556874 and DP0880789). Siri Seoule drew all the pottery illustrations. Christian Reepmeyer (James Cook University) identified the source of the obsidian found at the sites discussed. Feedback from David V. Burley, Arnaud Noury and Glenn R. Summerhayes helped place the Malakula pottery in the wider Lapita context. 


\section{References}

Anson, D. 1986. Lapita pottery of the Bismarck Archipelago and its affinities. Archaeology in Oceania 21(3):157-165. doi.org/10.1002/j.1834-4453.1986.tb00144.x.

Bedford, S. 2003. The timing and nature of Lapita colonisation in Vanuatu: The haze begins to clear. In C. Sand (ed.), Pacific archaeology: Assessments and prospects. Proceedings of the conference for the 50th anniversary of the first Lapita excavation, Kone-Nouméa, 2002, pp. 147-158. Les cahiers de l'archéologie en Nouvelle-Calédonie 15. Département Archéologie, Service des Musées et du Patrimoine de Nouvelle-Calédonie, Nouméa.

Bedford, S. 2006a. Pieces of the Vanuatu puzzle: Archaeology of the north, south and centre. Terra Australis 23. Pandanus Books, The Australian National University, Canberra. doi.org/10.22459/PVP.02.2007.

Bedford, S. 2006b. The Pacific's earliest painted pottery: An added layer of intrigue to the Lapita debate and beyond. Antiquity 80:544-557. doi.org/10.1017/S0003598X00094023.

Bedford, S. 2007. Crucial first steps into Remote Oceania: Lapita in the Vanuatu archipelago. In S. Chiu and C. Sand (eds), From Southeast Asia to the Pacific. Archaeological perspectives on the Austronesian expansion and the Lapita Cultural Complex, pp. 185-213. Centre for Archaeological Studies, Research Centre of Humanities and Social Sciences. Academia Sinica, Taipei.

Bedford, S. 2015. Going beyond the known world 3000 years ago: Lapita exploration and colonization of Remote Oceania, in C. Sand, S. Chiu and N. Hogg (eds), The Lapita Cultural Complex in time and space: Expansion routes, chronologies and typologies, pp. 25-47. Archeologia Pasifika 4. Institut d'archéologie de la Nouvelle-Calédonie et du Pacifique (IANCP), Nouméa.

Bedford, S. and J.-C. Galipaud 2010. Chain of islands: Lapita in the north of Vanuatu. In C. Sand and S. Bedford (eds), Lapita: Ancêtres Océaniens/Oceanic ancestors, pp. 122-137. Museé du quai Branly and Somogy, Paris.

Bedford, S., M. Spriggs, R. Regenvanu, C. Macgregor, T. Kuautonga and M. Sietz 2007. The excavation, conservation and reconstruction of Lapita burial pots from the Teouma site, Efate, central Vanuatu. In S. Bedford, C. Sand and S.P. Connaughton (eds), Oceanic explorations: Lapita and Western Pacific settlement, pp. 223-240. Terra Australis 26. ANU E Press, Canberra. doi.org/10.22459/TA26.2007.

Bedford, S., M. Spriggs, H. Buckley, F. Valentin, R. Regenvanu and M. Abong 2010. A cemetery of first settlement: The site of Teouma, South Efate, Vanuatu. In C. Sand and S. Bedford (eds), Lapita: Ancêtres Océaniens/Oceanic ancestors, pp. 140-161. Museé du quai Branly and Somogy, Paris.

Bedford, S., H. Buckley, F. Valentin, N. Tayles and N. Longga 2011. Lapita burials, a new Lapita cemetery and Post-Lapita burials from Malakula, northern Vanuatu, Southwest Pacific. Journal of Pacific Archaeology 2(2):26-48.

Bedford, S., M. Spriggs and R. Shing 2016. 'By all means let us complete the exercise': The 50-year search for Lapita on Aneityum, southern Vanuatu and implications for other 'gaps' in the Lapita distribution. Archaeology in Oceania 51:122-130. doi.org/10.1002/arco.5100.

Best, S. 2002. Lapita: A view from the east. New Zealand Archaeological Association Monograph 24. New Zealand Archaeological Association, Auckland.

Bronk Ramsey, C. 2013. OxCal program v4.2.4. Radiocarbon Accelerator Unit, University of Oxford. c14.arch.ox.ac.uk/oxcal/OxCal.html.

Burley, D.V. 2007. In search of Lapita and Polynesian plainware settlements in Vava'u, Kingdom of Tonga. In S. Bedford, C. Sand and S.P. Connaughton (eds), Oceanic explorations: Lapita and Western Pacific settlement, pp. 187-198. Terra Australis 26. ANU E Press, Canberra. doi.org/10.22459/ TA26.2007. 
Burley, D.V. and W.R. Dickinson 2004. Late Lapita occupation and its ceramic assemblage at the Sigatoka Sand Dune site, Fiji, and their place in Oceanic prehistory. Archaeology in Oceania 39:12-25. doi.org/ 10.1002/j.1834-4453.2004.tb00553.x.

Burley, D.V. and K. LeBlanc 2015. Obfuscating migration and exchange: The misconceptions of an Eastern Lapita Province. In C. Sand, S. Chiu and N. Hogg (eds), The Lapita Cultural Complex in time and space: Expansion routes, chronologies and typologies, pp. 173-184. Archeologia Pasifika 4. IANCP, Nouméa.

Burley, D.V., W.R. Dickinson, A. Barton and R. Shutler 2001. Lapita on the periphery. New data on old problems in the Kingdom of Tonga. Archaeology in Oceania 36(2):89-104. doi.org/10.1002/j.18344453.2001.tb00481.x.

Burley, D.V., A. Storey and J. Witt 2002. On the definition and implications of Eastern Lapita ceramics in Tonga. In S. Bedford, C. Sand and D. Burley (eds), Fifty years in the field: Essays in honour and celebration of Richard Shutler Jr's archaeological career, pp. 213-226. New Zealand Archaeological Association Monograph 25. New Zealand Archaeological Association, Auckland.

Chiu, S. and C. Sand 2005. Recording of the Lapita motifs: Proposal for a complete recording method. Archaeology in New Zealand 48(2):133-150.

Clark, G. 2007. Specialisation, standardisation and Lapita ceramics. In S. Bedford, C. Sand and S.P. Connaughton (eds), Oceanic explorations: Lapita and Western Pacific settlement, pp. 289-299. Terra Australis 26. ANU E Press, Canberra. doi.org/10.22459/TA26.2007.

Clark, G. 2010. The remote horizon: Lapita dispersal in Fiji-West Polynesia. In C. Sand and S. Bedford (eds), Lapita: Ancêtres Océaniens/Oceanic ancestors, pp. 212-223. Museé du quai Branly and Somogy, Paris.

Clark, G. and A.J. Anderson 2001. The pattern of Lapita settlement in Fiji. Archaeology in Oceania 36(2):77-88. doi.org/10.1002/j.1834-4453.2001.tb00480.x.

Constantine, A., C. Reepmeyer, S. Bedford, M. Spriggs and M. Ravn 2015. Obsidian distribution from a Lapita cemetery sheds light on its value to past societies. Archaeology in Oceania 50(2):111-116. doi.org/10.1002/arco.5064.

David, B., I.J. McNiven, T. Richards, S.P. Connaughton, M. Leavesley, B. Barker and C. Rowe 2011. Lapita sites in the Central Province of mainland Papua New Guinea. World Archaeology 43(4):576593. doi.org/10.1080/00438243.2011.624720.

Denham, T., C. Bronk Ramsey and J. Specht 2012. Dating the appearance of Lapita pottery in the Bismarck Archipelago and its dispersal to Remote Oceania. Archaeology in Oceania 47(1):39-46. doi.org/10.1002/j.1834-4453.2012.tb00113.x.

Galipaud, J.-C., C. Reepmeyer, R. Torrence, S. Kelloway and P. White 2014. Long-distance connections in Vanuatu: New obsidian characterisations for the Makué site, Aore Island. Archaeology in Oceania 49:110-116. doi.org/10.1002/arco.5030.

Green, R.C. 1979. Lapita. In J.D. Jennings (ed.), The prehistory of Polynesia, pp. 27-60. Harvard University Press, Cambridge, Mass. doi.org/10.4159/harvard.9780674181267.c3.

Green, R.C. 2003. The Lapita horizon and traditions—-Signature for one set of Oceanic migrations. In C. Sand (ed.), Pacific archaeology: Assessments and prospects. Proceedings of the conference for the 50th anniversary of the first Lapita excavation, Kone-Nouméa, 2002, pp. 95-120. Les cahiers de l'archéologie en Nouvelle-Calédonie 15. Département Archéologie, Service des Musées et du Patrimoine de Nouvelle-Calédonie, Nouméa. 
Hawkins, S., T.H. Worthy, S. Bedford, M. Spriggs, G. Clark, G. Irwin, S. Best and P. Kirch 2016. Ancient tortoise hunting in the Southwest Pacific. Nature: Scientific Reports 6:38317. doi.org/ $10.1038 /$ srep38317.

Hedrick, J.D. n.d. Archaeological investigation of Malo prehistory: Lapita settlement strategy in the northern New Hebrides. Unpublished draft PhD thesis, University of Pennsylvania, Philadelphia, PA.

Kirch, P.V. 1997. The Lapita peoples: Ancestors of the Oceanic world. Blackwell, Oxford.

Layard, J. 1942. The stone men of Malekula: The small island of Vao. Chatto and Windus, London.

Lipson, M., P. Skoglund, M. Spriggs, F. Valentin, S. Bedford, R. Shing, H. Buckley, I. Phillip, G. Ward, S. Mallick, N. Rohland, N. Broomandkhoshbacht, O. Cheronet, M. Ferry, T. Harper, M. Michel, J. Oppenheimer, K. Sirak, K. Stewardson, K. Auckland, A. Hill, K. Maitland, S. Oppenheimer, T. Parks, K. Robson, T. Williams, D. Kennett, A. Mentzer, R. Pinhasi and D. Reich 2018. Population turnover in Remote Oceania shortly after initial settlement. Current Biology 28(7):1157-1165 and Supplementary Information. doi.org/10.1016/j.cub.2018.02.051.

MaCall, G., R. LeMaitre, A. Malahoff, G. Robinson and P. Stephenson 1970. The geology and geophysics of the Ambrym Caldera, New Hebrides. Bulletin of Volcanology 34:681-696. doi.org/10.1007/bf025 96698.

Noury, A. 2005. Le reflet de l'âme Lapita. Essai d'interprétation des décors des poteries Lapita en Mélanésie et en Polynésie Occidentale entre 3300 et 2700 avant le présent. Noury éditions, Versailles.

Noury, A. 2013. Le Lapita: À l'origine des sociétés d'Océanie. Lulu, Paris.

Noury, A. and J.-C. Galipaud 2011. Les Lapita: Nomades du Pacifique. IRD Éditions, Marseille. doi.org/10.4000/books.irdeditions.653.

Petchey, F., A. Anderson, A. Zondervan, S. Ulm and A. Hogg 2008. New marine $\Delta$ R values for the South Pacific subtropical gyre region. Radiocarbon 50(3):373-397. doi.org/10.1017/S00338222 00053509 .

Posth, C., K. Nägele, H. Colleran, F. Valentin, S. Bedford, K. Kami, R. Shing, H. Buckley, R. Kinaston, M. Walworth, G. Clark, C. Reepmeyer, J. Flexner, T. Maric, J. Moser, J. Gresky, L. Kiko, K. Robson, K. Auckland, S. Oppenheimer, A. Hill, A. Mentzer, J. Zech, F. Petchey, P. Roberts, C. Jeong, R. Gray, J. Krause and A. Powell 2018. Language continuity despite population replacement in Remote Oceania. Nature Ecology and Evolution 2:731-740. doi.org/10.1038/s41559-018-0498-2.

Reimer, P.J., E. Bard, A. Bayliss, J.W. Beck, P.G. Blackwell, C. Bronk Ramsey, C.E. Buck, H. Cheng, R.L. Edwards, M. Friedrich, P.M. Grootes, T.P. Guilderson, D.L. Hoffmann, A.G. Hogg, K.A. Hughen, K.F. Kaiser, B. Kromer, S.W. Manning, M. Niu, Reimer, D.A. Richards, E.M. Scott, J.R. Southon, R.A. Staff, C.S.M. Turney and J. van der Plicht 2013. IntCal13 and Marine13 radiocarbon age calibration curves 0-50,000 years cal BP. Radiocarbon 55:1869-1887. doi.org/10.2458/azu_js_rc.55.16947.

Robin, C., M. Monzier and J.-P. Eissen 1993. Giant tuff cone and $12 \mathrm{~km}$-wide associated caldera at Ambrym Volcano (Vanuatu, New Hebrides Arc). Journal of Volcanology and Geothermal Research 55:225-228. doi.org/10.1016/0377-0273(93)90039-T.

Sand, C. 2001. Evolutions in the Lapita Cultural Complex: A view from the Southern Lapita Province. Archaeology in Oceania 36(2):65-76. doi.org/10.1002/j.1834-4453.2001.tb00479.x.

Sand, C. 2010. Lapita Calédonien. Archéologie d’un premier peuplement Insulaire Océanien. Collection Travaux et Documents Océanistes 2. Société des Océanistes, Paris. doi.org/10.4000/books.sdo.1128.

Sand, C. 2015. Comparing Lapita pottery forms in the Southwestern Pacific: A case study. In C. Sand, S. Chiu and N. Hogg (eds), The Lapita Cultural Complex in time and space: Expansion routes, chronologies and typologies, pp. 125-171. Archeologia Pasifika 4. IANCP, Nouméa. 
Sand, C., J. Bolé and A.-J. Ouetcho 2011. A revision of New Caledonia’s ceramic sequence. Journal of Pacific Archaeology 2(1):56-68.

Skoglund, P., C. Posth, K. Sirak, M. Spriggs, F. Valentin, S. Bedford, G. Clark, C. Reepmeyer, F. Petchey, D. Fernandes, Q. Fu, E. Harney, M. Lipson, S. Mallick, M. Novak, N. Rohland, K. Stewardson, S. Abdullah, M. Cox, F. Friedlaender, J. Friedlaender, T. Kivisild, G. Koki, P. Kusuma, A. Merriwether, F.-X. Ricaut, J. Wee, N. Patterson, J. Krause, R. Pinhasi and D. Reich 2016. Genomic insights into the peopling of the Southwest Pacific. Nature 538(7626):510-513 and Supplementary Information. doi.org/10.1038/nature19844.

Summerhayes, G.R. 2000. Lapita interaction. Terra Australis 15. Department of Archaeology and Natural History and the Centre for Archaeological Research, The Australian National University, Canberra.

Summerhayes, G.R. 2001. Lapita in the far west: Recent developments. Archaeology in Oceania 36(2):53-63. doi.org/10.1002/j.1834-4453.2001.tb00478.x.

Taylor, F.W., B.L. Isacks, C. Jouannic, A.L. Bloom and J. Dubois 1980. Coseismic and Quaternary vertical tectonic movements, Santo and Malekula, New Hebrides Arc. Journal of Geophysical Research 85, B10:5367-5381. doi.org/10.1029/JB085iB10p05367.

Valentin, F., F. Détroit, M. Spriggs and S. Bedford 2016. Early Lapita skeletons from Vanuatu show Polynesian craniofacial shape: Implications for Remote Oceanic settlement and Lapita origins. Proceedings of the National Academy of Sciences 113(2):292-297. doi.org/10.1073/pnas.1516186113. 
This text is taken from Debating Lapita: Distribution, Chronology, Society and Subsistence, edited by Stuart Bedford and Matthew Spriggs, published 2019 by ANU Press,

The Australian National University, Canberra, Australia.

doi.org/10.22459/TA52.2019.11 